\title{
The conversion of heights of the benchmarks of the detailed vertical reference network into the PL-EVRF2007-NH frame
}

\section{Łukasz Borowski $\oplus^{1 *}$ and Piotr Banasik $\oplus^{2}$}

\author{
${ }^{1}$ Department of Geotechnical Engineering, Faculty of Civil Engineering and Architecture, Lublin University of \\ Technology, Nadbystrzycka St. 40, 20-618, Lublin, Poland \\ ${ }^{2}$ Department of Integrated Geodesy and Cartography, Faculty of Mining Surveying and Environmental \\ Engineering, AGH University of Science and Technology, Mickiewicza Av. 30, 30-059, Kraków, Poland \\ *1.borowski@pollub.pl
}

\begin{abstract}
The paper describes the problem of conversion of heights to the European Vertical Reference Frame 2007 for Poland (PL-EVRF2007-NH). The subject of the study is height data, and especially the detailed vertical reference network. The aim of the article is to present an alternative method of conversion to the one recommended by the Polish Head Office of Geodesy and Cartography. The proposed approach is characterised by a low implementation cost while maintaining the required accuracy.

The publication is illustrated by the case of Kętrzyn district (in the north-east part of Poland). The local reference network was converted from Kronstad'60 to PL-EVRF2007-NH in 2017.
\end{abstract}

Key words: height conversion, detailed vertical reference network, PL-EVRF2007-NH, PL-KRON86-NH

\section{Introduction}

The problem of calculating height of the benchmarks of the vertical reference network should be examined in the context of features of a given height frame and the type of the vertical reference network.

Pursuant to the Ordinance of the National Spatial Reference System, heights of the reference network points should be expressed in the Kronstad Vertical Reference Frame 1986 for Poland (PL-KRON86-NH) and the European Vertical Reference Frame 2007 for Poland (PL-EVRF2007-NH) (Regulation, 2012b). However, as of 1 January 2020, the PL-EVRF2007-NH frame with the reference level of the North Sea in Amsterdam (Somla, 2018) will be binding. Therefore, it is necessary to develop a new vertical reference frame. Due to the division of the surveying resource existing in Poland, including geodetic control networks into main (basic networks) and district (detailed networks) control networks, the task of calculating the height is performed in two stages, according to the classification of the given network (Regulation, 2012a).

During the first stage, heights of the basic vertical reference network benchmarks in the PL-EVRF2007-NH (Graszka et al., 2016; Kadaj, 2018) frame were calculated. The Head Office of Geodesy and Cartography provides data in both above-mentioned height frames, as well as a model of height conversions between these frames (PL-KRON86-NH and PLEVRF2007-NH), developed for the area of the country (Head Office of Geodesy and Cartography, 2015). This article focuses on the second stage, that is, the conversion of height of the detailed reference network benchmarks. Although these works are already carried out in many districts, due to the diversified state of the detailed reference network, the use of different height frames and different financial means of the districts, the process of introducing the PL-EVRF2007-NH frame at the district level seems to be more complex. The article at- 
tempts to analyse selected aspects of height conversion in the detailed reference network. The proposed method based on height transformation in conditions of good saturation of the area with adjustment points may give results similar to those of the method of rigorous adjustment of levelling observations. The analysis is illustrated by an example of such conversion carried out for one of the districts.

\section{Characteristics of the vertical reference network and height frame}

The regulations concerning the classification of reference networks are contained in the Regulation on geodetic, gravimetric and magnetic control networks (Regulation, 2012a). The vertical reference network can be classified into basic fundamental, basic and detailed network. Such division corresponds to the accuracy of the network realised by classes 1,2 and 3 accordingly. Surveyor General of Poland is responsible for the basic reference network, whereas the starost (head) of a district is responsible for the detailed reference network. The basic classification criterion is 'the accuracy of determining the size (...) defined by the value of the average error of the determined size' (Regulation, 2012a). For the basic vertical reference network, this value should not exceed $1.5 \mathrm{~mm} / \mathrm{km}$ in spirit levelling. The results of the levelling measurement should be prepared in accordance with the comparative and thermal correction, the tidal correction and the levelling correction (normal) and permanent tide correction. Before aligning the observations, a detailed evaluation of the network should be carried out in order to calculate the values of average measurement errors (levelling line, random, systematic error and so on) (Regulation, 2012a). The calculation of benchmarks heights is, therefore, performed only by precision spirit levelling. Other methods of levelling are not allowed.

For the detailed reference network, the accuracy requirements are lower. First of all, apart from spirited levelling, satellite levelling is also allowed, which may be a convenient solution to the problem of levelling (e.g. in the case of terrain obstacles) (Banasik and Bujakowski, 2017). The average measurement error in this network should not exceed $4 \mathrm{~mm}$. The above-mentioned corrections, used in precision levelling, are not introduced to observations in the detailed reference network.

The above synthesis of regulations allows us to claim that the basic (national) reference network is established by geodetic methods (e.g. taking into account the influence of geodynamic phenomena), whereas the detailed (district) reference network is established by land surveying methods.

The introduction of the new state elevation frames was the result of successive measurement campaigns of the basic vertical reference network in Poland. Over the years, in addition to the development of measurement technology, the way in which the tidal phenomenon was included was also subject to change. The mean-tide system was replaced by the tide-free system, and then by the EVRS2007 system, which by definition is zerotide (Mäkinen, 2008). In the 1960s the error of the Potsdam system was observed (Barlik and Pachuta, 2007). The models of vertical movements of the Earth's crust were also more detailed and the constant value of the whole country's settlements of about $-2 \mathrm{~mm}$ /year (Kowalczyk, 2006) was abandoned. The monitoring of the state precise satellite positioning network stations (called ASG-EUPOS) carried out since 2008 has provided information on the simultaneous existence of settlement and uplift areas (Kontny and Bogusz, 2012; Maciuk, 2016; Maciuk and Szombara, 2018). The result of the above changes is the lack of a constant conversion between the PL-KRON86-NH and PL-EVRF2007-NH elevation frames in Poland. According to the model made available by the Head Office of Geodesy and Cartography (HOGC, pl. GUGiK), the difference is within the range from +12.8 to $+20.6 \mathrm{~cm}$, with an average value of +16.6 cm (Borowski et al., 2017).

The synthesis of the heights frames is presented in Table 1. The previous state and local frames are not included in it. These frames were simultaneously used until recently in some cities (e.g. in Warsaw or Ełk): the former Amsterdam (1926-1937), Kronstadt' 60 and Kronstadt' 86.

\section{The conversion of the elevation of the benchmarks of the detailed reference net- work}

One of the first works on the conversion of height between the Kronstadt' 60 and Kronstadt' 86 frames concerned the detailed reference network of Kraków district (Banasik et al., 2012). For this purpose, the authors used a polynomial transformation function, developed with the use of adjustment benchmarks coming from the basic reference network and with heights in both frames. The flat coordinates of the benchmarks necessary for transformation were obtained by digitalisation of the relevant cartographic materials.

Another study in this field concerned the detailed reference network in the Wrocław area (Osada et al., 2017; Osada and Gralak, 2017). The authors of this article applied a rigorous adjustment of archival observations from the levelling network, in relation to the benchmarks with known heights in the new frame. The whole procedure consisted of four stages, with each being adjusted in a different reference configuration. Most of the work preceding the calculation was related to the completion and preparation of observation data for adjustment.

In 2018, the first information on the conversion of the height of detailed reference networks to the PL-EVRF2007-NH frame (Graszka, 2018) appeared. Then, on the website of the GUGiK, the proposed methodology for height conversion (Head Office of Geodesy and Cartography, 2018) was published. The trainings in this field among district surveyors were also conducted (Królikowski, 2019).

The method recommended by GUGiK to calculate the height of the detailed reference network benchmarks is a rigorous adjustment of observations in the levelling network (Graszka, 2018; Head Office of Geodesy and Cartography, 2018; Somla, 2018). ${ }^{1}$ Three cases in which the detailed reference network can be found in particular districts are given (Table 2). Each of them is assigned a specific scope of activities. In the simplest situation there are districts where the vertical reference network was modernised and complete data are stored in electronic form. In such case, the recommendation to readjust the PL-EVRF2007-NH frame does not raise any doubts. It should not also cause any doubts in those districts where the complete modernisation of the reference network is planned. Adjustment of observations in the new frame will probably be one of the conditions for such modernisation.

There may be doubts in case 2 and 3 (Table 2). At least some of the 380 districts may have difficulties in financing this project. The reason is the higher priority of the horizontal reference network on which cadastral data are based, as well as the establishment and maintenance of district databases. The introduction of a new heights frame enforces investments in the vertical reference network, and the above recommendations of the GUGiK increase its value. The approximate costs of case no. 2 given in Table 2 seem to be underestimated. For

1 Transformation is only permitted for the measurement reference network and situational details. 
Table 1. Characteristics of selected elevation frames in Poland

\begin{tabular}{|c|c|c|c|}
\hline The name of elevation frame & $\begin{array}{l}\text { Measurement } \\
\text { campaign }\end{array}$ & $\begin{array}{l}\text { Average error } \\
\text { after adjustment } \\
{[\mathrm{mm} / \mathrm{km}]}\end{array}$ & Characteristics of the frame \\
\hline $\begin{array}{l}\text { Kronstadt'60 } \\
\text { (Wyrzykowski, 1993) }\end{array}$ & 1947-1958 & 0.78 & $\begin{array}{l}\text { - normal heights; } \\
\text { - gravimetric system Poczdam; } \\
\text { - Kronstadt level; } \\
\text { - mean-tide. }\end{array}$ \\
\hline $\begin{array}{l}\text { Kronstadt'86 } \\
\text { (Kowalczyk and Rapinski, } \\
\text { 2012; Łyszkowicz, 2012) }\end{array}$ & $1974-1982$ & 0.84 & $\begin{array}{l}\text { - normal heights; } \\
\text { - gravimetric system IGSN71; } \\
\text { - Kronstadt level; } \\
\text { - tide-free. }\end{array}$ \\
\hline $\begin{array}{l}\text { Kronstadt'2006 } \\
\text { (Gajderowicz, 2007; Kowal- } \\
\text { czyk and Rapinski, 2012) }\end{array}$ & $1999-2002^{b}$ & 0.88 & $\begin{array}{l}\text { - normal heights; } \\
\text { - gravimetric system IGSN71; } \\
\text { - Kronstadt level; } \\
\text { - tide-free. }\end{array}$ \\
\hline $\begin{array}{l}\text { PL-KRON86-NH } \\
\text { (Somla, 2018) }\end{array}$ & $\begin{array}{l}1974-1982 \\
1999-2002\end{array}$ & 0.91 & $\begin{array}{l}\text { - normal heights; } \\
\text { - gravimetric system IGSN71; } \\
\text { - Kronstadt level; } \\
\text { - tide-free. }\end{array}$ \\
\hline $\begin{array}{l}\text { PL-EVRF2007-NH } \\
\text { (Mäkinen, 2008; Somla, } \\
\text { 2018) }\end{array}$ & 1999-2012 & 0.91 & $\begin{array}{l}\text { - normal heights; } \\
\text { - gravimetric system GRS'80; } \\
\text { - Amsterdam level; } \\
\text { - zero-tide. }\end{array}$ \\
\hline
\end{tabular}

a The frame was not put into service.

$\mathrm{b}$ The years 1997-2003 are also quoted as part of the work was carried out in 1997 and 2003.

Table 2. The recommendations of the GUGiK concerning the conversion of heights depending on the state of data in districts (Somla, 2018)

\begin{tabular}{|c|c|c|c|}
\hline Case & The state of the reference network & Recommended method of height calculation & $\begin{array}{c}\text { Gross cost } \\
{[\text { PLN/point }]^{\mathrm{a}}}\end{array}$ \\
\hline 1 & $\begin{array}{l}\text { - has been modernised; } \\
\text { - the height in the PL-KRON86-NH frame; } \\
\text { - digitalised elevations. }\end{array}$ & Adjustment in PL-EVRF2007-NH frame & 10 \\
\hline 2 & $\begin{array}{l}\text { - not modernised; } \\
\text { - heights in the Kronstadt' } 86 \text { frame; } \\
\text { - there are data on elevations in levelling lines. }\end{array}$ & $\begin{array}{l}\text { Performing control measurements, data verification } \\
\text { and adjustment in the PL-EVRF2007-NH frame }\end{array}$ & 50 \\
\hline 3 & $\begin{array}{l}\text { - not modernised; } \\
\text { - heights in different frames; } \\
\text { - incomplete archival material. }\end{array}$ & $\begin{array}{l}\text { Modernisation of the reference network and adjust- } \\
\text { ment in the PL-EVRF2007-NH frame }\end{array}$ & 700 \\
\hline
\end{tabular}

${ }^{a}$ According to the Head Office of Geodesy and Cartography (Królikowski, 2019).

an 'average' district with 1000 points of vertical reference network, the financial outlays are as follows:

i. Collection of materials, digitalisation and preparation of data for adjustment - minimum 20,000 PLN

ii. Field review of points and completion of files (district geodetic database) - minimum 50,000 PLN

iii. Updating measurement - minimum 15,000 $\mathrm{PLN}^{2}$

iv. Reference network adjustment - minimum 10,000 PLN

v. Preparation of transformation and conversion of data in topographic objects database and the basic map - minimum 10,000 PLN. ${ }^{3}$

Thus, the real cost of elaboration may be even twice as high as estimated (case 2, Table 2). To confirm this, one can give an example of the reference network in Szczecinek district (of more than 900 points), where the cost of elaboration exceeded even the amount of 100 PLN per point (Fabisiak, 2019). Another example is the detailed reference network in Białystok, consisting of about 5400 points (Bialystok City Council, 2019). For this study, carried out without field-works and with a con-

2 The operation of the measurement team was assumed for 10 days for $1500 \mathrm{PLN} /$ day.

3 Fixed costs for all three considered examples. trol measurement only for $1.5 \%$ of points, the cost exceeded the GUGiK's estimates and amounted to over 60 PLN per point. Despite these significant costs, it is not certain whether the benchmarks of the reference network have not changed their location since the time of their measurement or have been destroyed (e.g. as a result of thermal modernisation of buildings). In order to eliminate the above factors, a full modernisation of the vertical reference network is necessary, which is a much more expensive operation (case 3 , Table 2 ).

There is some misunderstanding about the statement concerning the preparation for the rigorous adjustment of the levelling network, contained in the recommendations (Chapter II, point 2, subitem 5 (Head Office of Geodesy and Cartography, 2018)):

Before the adjustment of the detailed vertical reference network, it is necessary to reduce archival observations to one epoch and one reference frame, which requires knowledge about methods and accuracy of the observations and methods of their reduction ${ }^{4)}$

and in particular the explanation in the footnote ${ }^{4)}$ :

4) Archive observations of heights may use thermal correction and occasionally comparative correction, but do not usually use lunosolar and normal correction. 


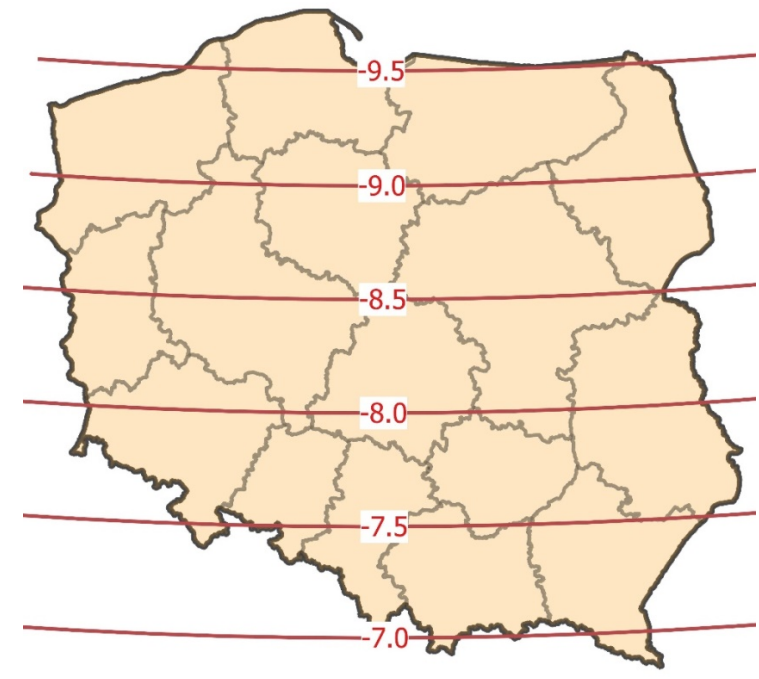

Figure 1. Distribution of height differences between mean-tide and zero-tide systems in Poland [cm] (own study based on Mäkinen (2008))

Therefore, a question arises whether, in connection with the above, archival levelling observations in a detailed vertical reference network should be provided with appropriate corrections (e.g. lunosolar (tidal) and normal corrections), if they are to be used for re-alignment in the PL-EVRF2007-NH frame. This question can be answered after analysing the provisions of the ordinance on the vertical reference network, in the part concerning the detailed vertical reference network (Regulation, 2012a). However, it is worth using this opportunity to provide the justification for these provisions.

Observations in any levelling network (i.e. raw levelling measurement) results include, among others, the temporary effect of tidal phenomenon during the measurement. Thus, the levelling network, measured at various time intervals, in which the lunosolar correction was not taken into account, will be similar to the mean-tide model used in the Kronstadt' 60 frame. The introduction of the lunosolar correction to the measured elevations 'transfers' those elevations to the 'tide-free' model that was used in the Kronstadt' 86 frame, or to the 'zero-tide' model (EVRF2007 frame). The biggest differences between the above-mentioned tidal models occur between the mean- and zero-tide models, or, in the case of our country, between the Kronstadt' 60 and PL-EVRF2007-NH frames (Mäkinen, 2008). Changing the tidal model used in these systems results in a difference in height of a few centimetres (Fig. 1). By converting this difference into a distance we get a value of a fraction of a millimetre per kilometre. Levelling (normal) correction will result in similarly small values. Therefore, we do not have to consider using tidal or normal correction in the detailed vertical reference network. In the use of archival measurement data, first of all, their completeness is important, as it enables the alignment of observations within the levelling network.

\section{A proposal for an alternative method of cal- culating the height}

There is no doubt that the best solution to the problem of calculating the height of the benchmarks in detailed vertical reference network is its modernisation. Only this way a reference network will be fully functional, and its benchmarks will have current heights in the new elevation frame. For districts that fall under case 2 or 3 (Table 2), until the modernisation of the vertical reference network, a bridge solution would be useful, ensuring sufficient data quality and at the same time low cost of development. The proposal for such solution consists of the following stages:

i. A preliminary check whether it is possible to perform the transformation - an analysis of data (e.g. geoportal.gov.pl data (Head Office of Geodesy and Cartography, 2019)). A necessary condition is a good saturation of the area with adjustment points that is, having heights in both frames.

ii. Preparation of data - in case of lack of flat coordinates $(x$, $y$ ) of points, obtaining them through digitalisation of survey maps of reference networks. The accuracy of mapping of archived points may be low, but this is not a significant problem (Banasik et al., 2012). It is enough that the accuracy of the flat coordinates is at the level of individual decametres.

iii. Preparation of profiles of height differences in levelling lines of the existing basic and detailed reference network, for which heights are available in two frames: the previously used frame (PUF) and the target one.

iv. Analysis of profiles, exclusion of outlying points and creation of a set of adjustment points.

v. Possible partial measurement verification of doubtful levelling lines.

vi. Development of a transformation model (function) from a previously used frame (Kronstadt' 60 or local) to the PLKRON86-NH frame $\left(\Delta H_{\text {PUF-KRON86 }}\right)$.

vii. Comparison of height differences between points in the previously used frame and in PL-KRON86-NH, according to formula (1) (Head Office of Geodesy and Cartography, 2018):

$$
\left|\Delta H_{A-B}^{P U F}-\Delta H_{A-B}^{K R O N 86}\right|<0.02 \mathrm{~m}
$$

where: $\Delta H_{A-B}$ - elevation between point $\mathrm{A}$ and $\mathrm{B}$, PUF, KRON86 - previously used frame and the PL-KRON86$\mathrm{NH}$ frame. The analysis can be used to select levelling sections for control measurements.

viii. Comparison of height differences between PL-KRON86$\mathrm{NH}$ and PL-EVRF2007-NH calculated for adjustment points from catalogue data and GUGiK height differences model. ix. Development of the final transformation model between the frame used in the area and the PL-EVRF2007-NH frame $\left(\Delta H_{\text {PUF-EVRF2007 }}\right)$.

$\mathrm{x}$. Final conversion of all points to the new frame.

The above proposal assumes resignation from the rigorous adjustment and the need to perform field-work. In this manner, the most expensive elements of the development are minimised. The financial outlays for the 'average' district should amount to:

i. Collection of materials, digitisation and preparation of data - minimum 5000 PLN.

ii. Updating measurement - minimum 15,000 PLN.

iii. Preparation of transformation and conversion of data in district database and the basic map - minimum 20,000 PLN.

Thus, the cost of conversion of the heights should amount to approximately 25 PLN per point of the vertical reference network for office works only. Introduction of small measurement works doubles this number. The total amount of such conversion should not exceed 30,000 EUR ( 130,000 PLN). The procedure for selection of the contractor may therefore be carried out on the basis of a request for quotation. In comparison with the tender procedure, this is a procedure with a shorter formal timeframe before the actual works are commenced. For districts that 'postpone' the conversion, the use of the tender procedure may result in exceeding of the deadline imposed by the regulation for the introduction of the new frame. 


\subsection{The description of the procedure - an example of Kętrzyn district}

A detailed description of the proposed procedure is illustrated with an example of Kętrzyn district ${ }^{4}$, where the Kronstadt' 60 frame was used so far. The height conversion was done before the publication of the GUGiK recommendations.

In the method proposed above, rigorous adjustment was omitted. This significantly reduces the cost of data acquisition. Determining the coordinates of points through digitalisation is cheaper than scanning and laborious processing of the lists of elevations, especially in the case when there are several operators of the vertical reference network in a given district. The second factor that helps to reduce the cost is resignation from the field-works for all points. The example given in Section 3 indicates that this part of the work represents almost $50 \%$ of the order value. It seems that the field review of all points is an unnecessary expenditure, with little added value.

Before starting further works, it is recommended to supplement the geodetic network database with missing elements, such as non-digitalised topographic descriptions, corrections of entries in the database ${ }^{5}$, or conversion of coordinates $(x, y)$ to the single, national coordinate system.

The initial control element of the reference network is the creation of profiles of differences of levelling lines (Banasik et al., 2012). Profiles with straight lines are particularly important. Four profiles of such characteristics can be identified in the Kętrzyn district area. The analysis of one of them is shown in Fig. 2. It is clearly visible that points 140 and 150 stand out (Fig. 2a). Excluding these points from the data set smoothens the profile (Fig. 2b). It would be advisable to use a function fit so that the adjustment of the profile to the function can be observed when further points are excluded. In this example, the second-degree polynomial (Eq. (2)) and the Pearson correlation coefficient $\left(R^{2}\right)$ are used. The value of 0.7 was assumed to be sufficient correlation to stop further analysis. Basing on this analysis, places to perform control measurements can be indicated. For example, points 140 and 150 have significantly changed their height in comparison to the others and a control measurement could explain the reason for this. For this reason, the authors recommend allocating part of the district funds to this type of measurements. However, this was not done in Kętrzyn district. The above analysis allowed the identification of outlying points for which the investigation should be carried out. The reason for the height discrepancy may be:

- change in altitude between measurement campaigns (vertical displacement),

- destruction of the benchmark and its reconstruction at a different altitude,

- assigning an incorrect height in data-base.

The first thing to do is to check the available documentation on these points (topographic descriptions, orthophotomaps and so on). In this way, you can detect the points displacement due to change in topography or reproduction of damaged markers. Only those points for which no relevant information was found during the office works should be subjected to the field review. At the same time, the field-works should concern only the points of the detailed reference network. The GUGiK should be informed about possible height errors for the basic reference network points.

4 License for scientific and educational purposes for the data of the reference network no. GKN-0.6642.1.1992.2017_2808_N issued by the Starost of Kętrzyn.

5 There may be errors in geodetic database records, for example in the field of 'frame height 1 ' there are given heights from the Kronstadt' 60 and PL-KRON86-NH frames.

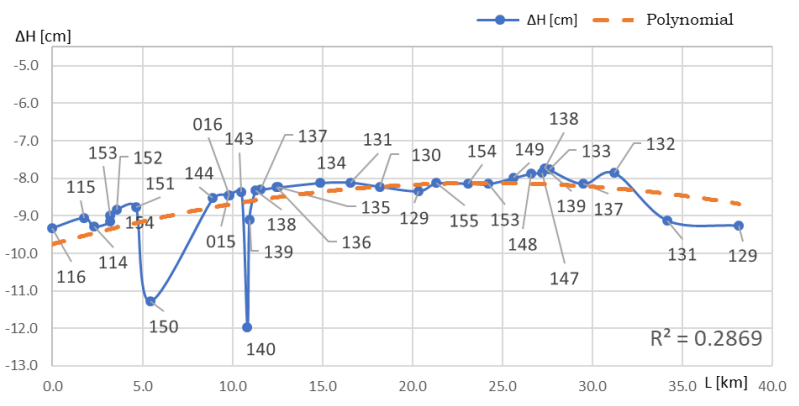

(a) $\Delta H$ before exclusion of outlying points

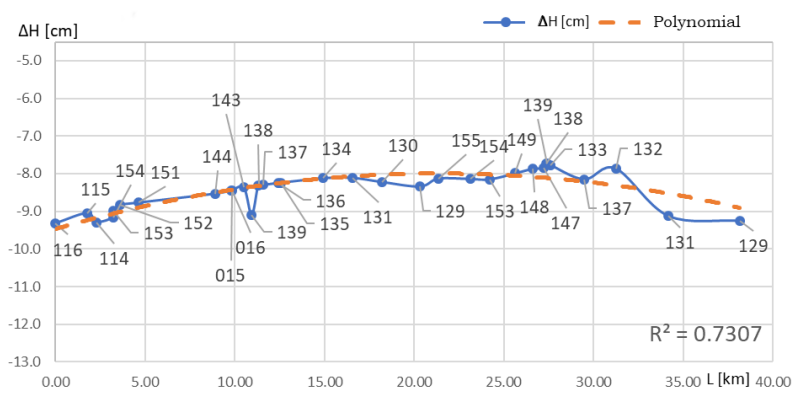

(b) $\Delta H$ after exclusion of points 140 and 150

Figure 2. Height differences $\Delta H$ between the Kronstad'60 and PLEVRF2007-NH frames of the points of the basic reference network of Kętrzyn district along the N-S profile

In Kętrzyn district the update measurements of detailed vertical network were completely omitted. Out of 108 points selected for the development of the conversion model, 104 belonged to the basic reference network. The preliminary analysis showed discrepancies on 14 points of the basic reference network. At these points, the differences between the frames significantly diverged from the others, in three cases with the opposite sense. The remaining points (94) were sufficient to develop the transformation function, with a relatively good distribution in the area of the district (Fig. 3). The only area without a basic reference network is located in the north-eastern part of the district. It is a densely forested area with a low degree of urbanisation.

The next stage of work was development of a transformation model. For this purpose, the second-degree polynomial with six parameters (Eq. (2)) was used.:

$$
f_{\Delta H}(x, y)=a_{00}+a_{10} x+a_{01} y+a_{11} x y+a_{20} x^{2}+a_{02} y^{2}
$$

where: $f_{\Delta H}(x, y)$ - transformation function (heights conversion), $a_{00}, a_{10}, \ldots$ - function coefficients, $x, y$ - flat coordinates of the points. This is a widely used function, among the others, to model a quasi-geoid in small areas (Tusat and Mikailsoy, 2018; Walo, 2000). Polynomial optimisation was performed with the use of one of the robust estimation methods - the Danish method. It gives a better fit than the least square adjustment method (Banaś, 2012; Borowski and Banaś, 2018). As a result, the distribution of height shifts improved (Table 3) (Borowski, 2017). The extreme values of displacement between the frames were approximately $2.7 \mathrm{~cm}$, which gives a value below $1 \mathrm{~mm} / \mathrm{km}$.

The height difference $\Delta H_{\text {Kronstadt }^{\prime} 60-\mathrm{KRON} 86}$ in the grid nodes $0.1^{\circ} \times 0.1^{\circ}$ was calculated on the basis of the model. The grid of this resolution is also used in the national elevation difference model $\left(\Delta H_{\text {KRON86-EVRF2007 }}\right)$ (Head Office of Geodesy and Cartography, 2015). The final model $\Delta H_{\text {Kronstadt' } 60-E V R F 2007}$ was the sum of the values in the nodes 
Table 3. The assessment of the accuracy of the model $\Delta H_{\text {Kronstadt' 60-KRON86: }}$ raw data (the points of the reference network) and after adjustments (the Danish method)

\begin{tabular}{lcc}
\hline Parameter & Raw data & $\begin{array}{c}\text { The Danish } \\
\text { method }\end{array}$ \\
\hline Average $[\mathrm{cm}]$ & -8.2 & -8.2 \\
Deviation $[\mathrm{cm}]$ & 0.9 & 0.6 \\
Maximum [cm] & -6.4 & -6.9 \\
Minimum [cm] & -10.5 & -9.6 \\
Curtosis & -0.11 & -0.04 \\
Skewness & -0.24 & -0.01 \\
\hline
\end{tabular}

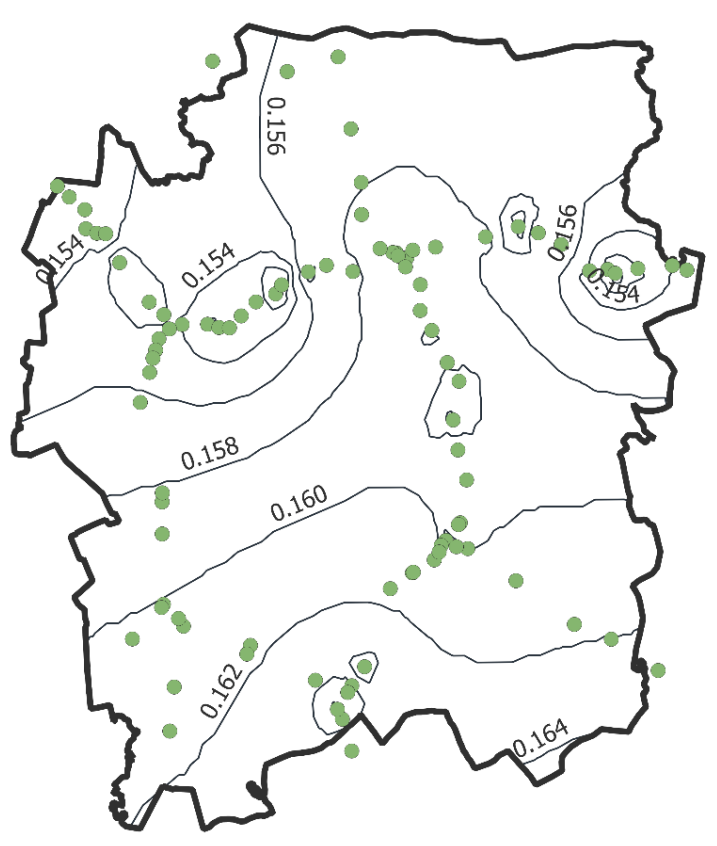

Figure 3. The scheme of distribution of the points of basic reference network used for the construction of the model of height conversion from Kronstadt'60 to PL-EVRF2007$\mathrm{NH}$ in the area of Kętrzyn district (height difference isolines are given in $\mathrm{m}$ )

of both grids ( $\Delta H_{\text {Kronstadt' } 60-K R O N 86}+\Delta H_{\text {KRON86-EVRF2007 }}$ ). The height at any point of the district resource was calculated by interpolation of the obtained grid, according to the formulas from instruction G-1.10 (Kadaj, 2001). Alternatively, it is also possible to fit the polynomial (2) into the state model. The calculation of the value at any point is then carried out on the basis of both models.

The control of matching the points of basic reference network with the GUGiK model was performed with the use of the author's software, using interpolations according to the G1.10 instruction. The average difference between KRON86 and EVRF2007 was less than $0.8 \mathrm{~mm}$. This insignificant value made it possible to use the above-mentioned nodes grid without any additional processing.

\section{Summary}

The article presents an alternative method of heights conversion from the previous height frames to the PL-EVRF2007-NH frame, which is in use for the detailed reference network. This method uses height transformation, through a function developed for selected adjustment benchmarks. The adopted solu- tion is based on the method used in Cracow district (Banasik et al., 2012), or local modelling of a quasi-geoid (Walo, 2000).

The main advantage of the proposed method is the lower cost of its implementation, with the accuracy acceptable for a detailed vertical reference network. The cost of such study should range from 25 PLN per point (without field works) to 40 PLN per point (limited field-works), for an 'average' district of about 1000 points. This is lower than the amount estimated by the GUGiK (case 2, Table 2). It should be assumed that the given amount of 50 PLN per point is clearly underestimated. Due to lower development costs the proposed method may be attractive especially for districts with a limited budget.

\section{References}

Banaś, M. (2012). A review of robust estimation methods applied in surveying. Geomatics and Environmental Engineering, 6(4):13-22, doi:10.7494/geom.2012.6.4.13.

Banasik, P. and Bujakowski, K. (2017). The use of quasigeoid in leveling through terrain obstacles. Reports on Geodesy and Geoinformatics, 104:57-64, doi:10.1515/rgg-2017-0015.

Banasik, P., Ligas, M., Kudrys, J., Skorupa, B., and Bujakowski, K. (2012). Transformacja wysokości z układu Kronsztadt' 60 do układu Kronsztadt' 86 na przykładzie powiatu krakowskiego. Przegląd Geodezyjny, 84(4):6-13.

Barlik, M. and Pachuta, A. (2007). Geodezja fizyczna i grawimetria geodezyjna: Teoria i praktyka. Oficyna Wydawnicza Politechniki Warszawskiej.

Bialystok City Council (2019). Przeliczenie szczegółowej osnowy wysokościowej (dawna III i IV klasa), punktów szczegółowej osnowy poziomej posiadających wysokości oraz rzędnych szczegółów sytuacyjno-wysokościowych do państwowego układu wysokościowego PL-EVRF2007-NH. Bialystok City Council, Public procurement no. DGEI.271.6.2019.

Borowski, Ł. (2017). Opracowanie transformacji wysokości z układu Kronszatd'60 do PL-EVRF2007-NH dla powiatu kętrzyńskiego.

Borowski, Ł. and Banaś, M. (2018). Application of robust estimation in polynomial modelling. In 2018 Baltic Geodetic Congress (BGC Geomatics), pages 62-66. IEEE, doi:10.1109/BGC-Geomatics.2018.00018.

Borowski, Ł., Lal, A., and Nepelski, K. (2017). Analiza osiadania wybranych typów znaków osnowy geodezyjnej. Budownictwo i Architektura, 16(3):135-142, doi:10.24358/BudArch_17_163_13.

Fabisiak, R. (2019). Reply no. BOI.1431.39.2019.MŁ. County Executive Szczecinek.

Gajderowicz, I. (2007). Propozycja nowego polskiego układu wysokościowego. Geomatics and Environmental Engineering, 1(1):125-132.

Graszka, W. (2018). Porządkowanie wysokości. Geodeta: Magazyn Geoinformacyjny, 272(1):10-15.

Graszka, W., Pielasa, E., Wajda, S., and Piętka, D. (2016). Podstawowa osnowa wysokościowa, grawimetryczna i magnetyczna - ocena stanu i prognozy rozwoju. Współczesne problemy podstawowych osnów geodezyjnych w Polsce. Grybów. Retrieved from: http://www.rogopen.gik.pw.edu.pl/ phocadownload/Gryb_2016/Sesja_3/Graszka_el_al_2016.pdf.

Head Office of Geodesy and Cartography (2015). Model różnic wysokości pomiędzy układami wysokościowymi PL-EVRF20o7NH i PL-KRON86-NH. Retrieved from: http://www.gugik. gov . pl/__data/assets/text_file/0016/1843/gugik-evrf2007.txt.

Head Office of Geodesy and Cartography (2018). Przeliczanie szczegółowej osnowy wysokościowej, pomiarowej osnowy wysokościowej oraz rzędnych szczegótów sytuacyjnowysokościowych do państwowego układu wysokoś- 
ciowego PL-EVRF2007-NH. Retrieved from: http: //www.gugik.gov.pl/__data/assets/pdf_file/0004/96142/ Warunki-przeliczenia-do-ukladu-PL-EVRF2007-NH.pdf.

Head Office of Geodesy and Cartography (2019). Podstawowa Osnowa Pozioma dostępna do pobrania przez powiaty - Informacje. Retrieved from: https://www.geoportal.gov.pl.

Kadaj, R. (2001). Wytyczne Techniczne G-1.10: Formuly odwzorowawcze i parametry układów wspótrzędnych. Warsaw, Head Office of Geodesy and Cartography.

Kadaj, R. (2018). Transformations between the height reference frames: Kronsztadt'60, PL-KRON86-NH, PLEVRF2007-NH. Journal of Civil Engineering, Environment and Architecture, 65(3):5-24, doi:10.7862/rb.2018.38.

Kontny, B. and Bogusz, J. (2012). Models of vertical movements of the earth crust surface in the area of Poland derived from leveling and GNSS data. Acta Geodynamica et Geomaterialia, 9(3):331-337.

Kowalczyk, K. (2006). Cały kraj się obsuwa. Geodeta: Magazyn Geoinformacyjny, 135(8):45-48.

Kowalczyk, K. and Rapinski, J. (2012). Adjustment of vertical crustal movement network on the basis of last three leveling campaigns in Poland. Reports on Geodesy and Geoinformatics, 92:123-134.

Królikowski, J. (2019). Jak przeliczać osnowę do układu PLEVRF2007-NH? Retrieved from: https://geoforum.pl/news/ 26493/jak-przeliczac-osnowe-do-ukladu-pl-evrf2007-nh-.

Łyszkowicz, A. (2012). Podstawowa osnowa wysokościowa w Polsce. Współczesne problemy podstawowych sieci geodezyjnych. Grybów.

Maciuk, K. (2016). The study of seasonal changes of permanent stations coordinates based on weekly EPN solutions. Artificial Satellites, 51(1):1-18, doi:10.1515/arsa-2016-0001.

Maciuk, K. and Szombara, S. (2018). Annual crustal deformation based on GNSS observations between 1996 and 2016 .
Arabian Journal of Geosciences, 11(21):667, doi:10.1007/s12517018-4022-4.

Mäkinen, J. (2008). The treatment of permanent tide in EUREF products. In Symposium of the IAG Sub-commission for Europe (EUREF) in Brussels.

Osada, E. and Gralak, H. (2017). Metoda przeliczania szczegółowych osnów wysokościowych z układu PLKRON86-NH do układu PL-EVRF2007-NH. Przegląd Geodezyjny, 89(6):20-23, doi:10.15199/50.2017.6.3.

Osada, E., Siudziński, K., Drąg, A., Gralak, H., Siręga, K., Kurpiński, G., and Seta, M. (2017). Procedura optymalnego planowania i wykonywania pomiaru aktualizacyjnego szczegółowych osnów wysokościowych przeliczonych z układu PL-KRON86-NH do układu PL-EVRF2007-NH. Przegląd Geodezyjny, 89(12):15-17, doi:10.15199/50.2017.12.2.

Regulation (2012a). Regulation of the Minister of Administration and Digitization of February 14, 2012 regarding geodetic, gravimetric and magnetic networks. Official journal 2012, item 352.

Regulation (2012b). Regulation of the of the Council of Ministers of October 15, 2012 on the national spatial references systems. Official journal 2012, item 1247.

Somla, J. (2018). Zasady przeliczania szczegółowej osnowy wysokościowej do układu PL-EVRF2007-NH. Spotkanie Geodetów Powiatowych Warszawa, 28-29 November 2018, pages 28-29.

Tusat, E. and Mikailsoy, F. (2018). An investigation of the criteria used to select the polynomial models employed in local GNSS/leveling geoid determination studies. Arabian Journal of Geosciences, 11(24):801, doi:10.1007/s12517-018-4176-0.

Walo, J. (2000). Analiza wybranych algorytmów wyznaczania lokalnego przebiegu geoidy. $\mathrm{PhD}$ thesis, Warsaw University of Technology.

Wyrzykowski, T. (1993). Rys historyczny podstawowej osnowy wysokościowej w Polsce. In Niwelacja precyzyjna. Warszawa-Wrocław: PPWK im. E. Romera S.A. 